inland lakes in Bechuanaland to the Indian Ocean and the Atlantic. His remedy was to divert these rivers back into their original courses. This scheme is now once more being considered, together with large-scale irrigating proposals.

Over most of the country, the poverty of the soil makes it more suitable for stock-farming, which, however, brings its own problems of animal disease, parasitic and nutritional. The Veterinary Research Institute at Onderstepoort, probably the largest in the world, is tackling these problems. The country is also well provided with agricultural colleges, experimental farms and research stations. The Low Temperature Station in Cape Town has produced improved methods for preserving and transporting food. Mention should be made of the sugar-cane production of the west sub-tropical belt, with its special experimental and research station. Afforestation is being carried out on a large scale by the Division of Forestry to make up for lack of natural forests ; the Division of Soil and Veld Conservation is coping with problems of erosion and with the education of farmers; the locust has its special research department. Yet much more research is needed before the land can be properly utilized.

The need for industrialization is obvious and urgent, as the gold industry, based as it is on the moribund gold-standard, has a precarious future, and the smaller diamond industry shows signs of reduction in importance. This need can only be solved by the application of science on a much larger scale than at present. However, the supply of trained scientific workers, especially in the physico-chemical sciences, from the four universities of the Union will have to be materially increased to meet this need.

\section{STUDIES OF ATMOSPHERIC POLLEN}

M. H. A. HYDE, keeper of the Department of I Botany in the National Museum of Wales, and Dr. D. A. Williams, of Llandough Hospital, Cardiff, have previously published (New Phytol., 43, 49; 1944) an important census of atmospheric pollens at Cardiff compiled during 1942 as a first publication in their studies of aerial pollen, which they have since termed 'palynology' (see Nature, 155, 264; 1945). In this they showed that, in the aggregate, grass pollens formed 75 per eent of the total pollen deposit caught (by a gravity slide method).

Their observations upon grass pollen have been greatly extended since, and the second part of their "Studies in Atmospheric Pollen" (New Phytol., 44, $83 ; 1945)$ is devoted to the diurnal variation in the incidence of grass pollen which they have demonstrated. Preliminary experiments in 1943 and more detailed experiments in 1944 with the exposure, for two-hourly periods throughout the day and night, of gravity and 'impact' slides (the latter mounted vertically and kept at right-angles to the direction of the wind) are recorded together with relevant meteorological data. The results from a site in good grassland and another upon the hospital roof near by were in good agreement and enable the authors to draw definite conclusions.

The 'impact' catch was always the more sensitive index of the amount of atmospheric pollen, which was found to follow closely the times of mass anthesis of the local grasses when pollen is liberated in large quantities. On fine, sunny days the principal grasses (Festuca rubra and Holcus lanatus) flowered slightly in the morning and profusely in the late afternoon, and this was reflected, immediately, in the relative heights of the pollen maxima which were obtained at these times. On the days when Arrhenatherum elatius, with its early morning anthesis, flowered there was a greater pollen maximum in the morning. Consequently, the time of maximum pollen concentration is likely to depend upon the predominant grass in the neighbourhood. On dull days anthesis was suppressed largely and local pollen concentrations remained low. When such a day was followed by one of bright sunshine exceptionally high concentrations were recorded. Rain may clear the air of pollen.

The authors quote another experiment at St. Mary's Hospital, Paddington, London, and from all their results disagree with Rempe's conclusion that, during day-time, large quantities of pollen are carried to a considerable altitude, and sediment, often at great distances, during the night. They ascribe this disagreement to the different conditions obtaining with tree pollen which formed most of Rempe's samples.

\section{LIFE-HISTORY OF PANDALUS BOREALIS}

THIS prawn is of commercial importance both in Atlantic and Pacific waters. In Norway, researches have been carried on in connexion with its life-history, the latest published results being those of Birger Rasmussen ${ }^{1}$.

Samples were collected continuously from Vigrafjord on the west coast of Norway, during September 1943-May 1944, and the material treated in the same way as in the author's former paper, on prawns from Spitsbergen ${ }^{2}$.

The pelagic larval stages are not dealt with, the smallest prawns caught on the bottom measuring $43.5 \mathrm{~mm}$. in length at the end of September when they are about five months old, and at $1 \frac{1}{2}$ years they have reached a length of $88 \mathrm{~mm}$. Most of these small prawns of $1 \frac{1}{2}$ years are sexually mature males.

The most interesting facts about these prawns are the sex changes. The age-group of $1 \frac{1}{2}$ years old chiefly consists of males spawning for the first time; but a few of these, and the largest individuals, are found in a transitional stage between male and female, maturing later as ovigerous females.

The group of mature males of $1 \frac{1}{2}$ years old at the end of December splits into two, one retaining the male characters, the other changing to a transitional stage later to ripen into females. Here again the larger prawns in the age group become females and the rate of growth after the division is greater in the females than in the remaining males.

The individuals of $2 \frac{1}{2}$ years old which have spawned twice as males during the following winter go over to the transitional stage and gradually change into females which spawn for the first time as females when $3 \frac{1}{2}$ years old.

The population of ovigerous prawns in the Vigrafjord is mainly composed of $2 \frac{1}{2}$ year-old first-time spawners, those of $1 \frac{1}{2}$ and $3 \frac{1}{2}$ years being scarcer. Prawns of $1 \frac{3}{4}$ years old may constitute 92 per cent of the catch and as they become older their number decreases rapidly.

1 Trekk fra dypvannsrekens biologi i norske kystfarvann. I. Vigrafjorden, Møre. Fiskeridirektoratets Skrifter. Serie Investigations. Vol. 8, No. 2. Published by the Director of Investigations. Vol. 8, No. 2. Published by the Director of Figure-texts. (Bergen, 1945.)

${ }^{2}$ Fiskeridirektoratets Skrifter. Serie Havundersgkelser. Vol. 7, No. (1942.) 